\title{
RAISING OF
}

\section{ARGUMENTAL NOUN PHRASE \\ IN BRAZILIAN PORTUGUESE \\ UNDER THE FUNCTIONAL \\ PERSPECTIVE: PRELIMINARY RESULTS}

\section{ALÇAMENTO DE SN ARGUMENTAL NO PORTUGUÊS BRASILEIRO SOB PERSPECTIVA FUNCIONALISTA: RESULTADOS PRELIMINARES}

ELEVACIÓN DE SN ARGUMENTAL EN EL PORTUGUÉS DE BRASIL DESDE LA PERSPECTIVA FUNCIONALISTA: RESULTADOS PRELIMINARES

ABSTRACT: Raising is defined in the literature as the codification of the noun phrase (NP) argument of the predicate attached to the edge of a predicate matrix, with which it contracts morphosyntactic relationships; thus, the semantic relationships of NP elevation with the predicate embedded are preserved, but they are broken down the morphosyntactic relationship between them (NOONAN, 2007). Building on different types of raising expressed in different languages (NOONAN, 2007; GÁRCIA VELASCO, 2013), the present paper aims to extract relevant properties for the description of a specific type of Raising in Brazilian Portuguese (BP): Subject-to-Subject Raising (SSR).

Keywords: Raising. Completive sentences. Subject.

RESUMO: Alçamento é definido na literatura como a codificação de sintagma nominal (SN) argumento do predicado encaixado aos limites do predicado da oração matriz, com o qual contrai relações morfossintáticas; são preservadas, assim, as relações

\footnotetext{
* Postgraduate student, in PhD level, in Linguistic Studies at Unesp/SJRP. He has experience in Linguistics, acting on the following topics: subject, raising of constituents, transparency, functional syntax and completive. E-mail: andrade.ibilce@gmail.com.

${ }^{1}$ This study was financed by the Coordenação de Aperfeiçoamento de Pessoal de Nível Superior - Brasil (CAPES) Finance Code 001 .
} 
semânticas do SN alçado com o predicado encaixado, mas há uma quebra na sua relação morfossintática (NOONAN, 2007). A partir de diferentes tipos de alçamento expressos em diferentes línguas (NOONAN, 2007; GÁRCIA VELASCO, 2013), este trabalho tem como objetivo extrair propriedades relevantes para a descrição de um tipo específico de Alçamento no Português Brasileiro (PB): Alçamento de Sujeito a Sujeito (ASS).

Palavras-chave: Alçamento. Orações completivas. Sujeito.

RESUMEN: Elevación se define en la literatura como la codificación de un sintagma nominal (SN) argumento del predicado encajado en los límites del predicado de la oración matriz, con el cual contrae relaciones morfosintácticas; se conservan, así, las relaciones semánticas del SN elevado con el predicado encajado, pero hay una ruptura en su relación morfosintáctica (NOONAN, 2007). A partir de diferentes tipos de elevación expresado en diferentes idiomas (NOONAN, 2007; GÁRCIA VELASCO, 2013), este trabajo tiene como objetivo extraer las propiedades relevantes para la descripción de un tipo específico de Elevación en portugués de Brasil (PB): la Elevación de Sujeto a Sujeto (SSR).

PALABRAS CLAVE: Elevación. Oraciones completivas. Sujeto.

\section{INTRODUCTION ${ }^{2}$}

Among the many phenomena that are manifested in the organization of complex sentences, here understood as strict cases of sentential subordination (HOPPER; TRAUGOTT, 2003; GONÇALVES et al., 2008), the raising of argumental constituent of the subordinate clause to the limits of the matrix clause is perhaps one of the most intriguing in natural languages (SERDOBOL'SKAYA, 2008), the reason I provide, in this paper, a description of the exploratory phenomenon for Brazilian Portuguese (BP) under the functionalist perspective, which implies the necessity to consider, in addition to morphosyntactic aspects, more routinely exploited, and also semantic and pragmatic aspects.

In line with the theoretical approach adopted, I undertake the description of the aforementioned raising based on research in a corpus of spoken language, starting at the typological work on complex clauses by Noonan (2007). I draw on the author with the aim of verifying whether the criteria used by him in the characterization of the phenomenon are necessary and sufficient for the identification and description of a specific case of BP raising: the raising of constituent subject of the subordinate clause to the position of constituent subject of the matrix clause (SSR, henceforth).

For data collection, I used the speech samples of IBORUNA, a medium-scale database (available at $<$ http://www.iboruna.ibilce.unesp.br>) with just over one million words. The database keeps records of the variety of Portuguese spoken in the countryside of the state of São Paulo through a sample of the linguistic census comprising part of the state's northwest region and a sample interaction, secretly recorded (GONÇALVES, 2007) in contexts of free social interaction with no control of social variants.

Based on the literature about the subject, I adopt the following parameters for describing and analysing the data:

(i) the morphosyntactic context: (a) [+/- agreement] raised NP in limits of matrix clause, (b) [+/- agreement] raised NP in limits of embedded clause, (c) presence of copy pronoun in the embedded clause, (d) type of connector between matrix and embedded, (e) format of embedded clause;

(ii) the semantic context: (a) semantic type of predicate matrix, (b) referentiality and (c) animacy of raised NP;

(iii) the pragmatic context: (a) topicality and (b) informational status of the raised NP.

${ }^{2}$ I thank Prof. MA. Guilherme Augusto Louzada Ferreira de Morais for the initial reading of this text. Other mistakes are my responsibility. 
Having exposed, the objectives of the present studyand its methodological apparatus in this introductory section, this study is structured into the following sections: section (2.) I present the theoretical background from where our description work starts; in section (3.) I show how the phenomenon manifests itself in BP from occurrences in the corpus, with special interest for cases of SSR; (3.1.) to conclude, I present the final remarks that points to a need for further investigation of the subject, in search of a more precise definition for the phenomenon, consistent with a functionalist approach.

\section{THEORETICAL SUPPORT}

In his work about the description of clausal complementation, Noonan (2007) deals with predicates that take clauses for complement and shows a typological treatment for completive clauses. When considering the syntax of clausal complementation, the author presents phenomena involved in the structuring of completive clauses, among which I highlight cases of raising, the central focus of attention in the present study. According to the author, depending on the type of matrix predicate and the phenomenon of equi-deletion ${ }^{3}$, completive clauses may still be subject to raising of the argumental noun phrases (NP), which is the occurrence, in the slot of the matrix clause, of an argumental NP of the predicate of the completive clause. Within this new structural domain, the raised NP contracted some type of morphosyntactic relation with the predicate, remaining, however, the semantic relation with the embedded predicate, as in the example from below taken from the author himself(NOONAN, 2007, p. 79).

(1) a. Irv believes [Harriet is a secret agent]

b. Irv believes Harriet [to be a secret agent]

In (1a), the Harriet NP occupies the argumental position of subject of embedded predicate secret agent, and, in (1b), it occurs in argumental position of object of matrix predicate believes, but it maintains the semantic relation with the embedded predication, which has its finite form reduced to a non-finite. Thus, the construction (1b), counterpart with raised NP (1a), represents a case of subject to object raising (hereafter, SOR). From this initial example, it should be clear that raising does not modify the semantic relations between a predicate and its arguments, it just resets the morphosyntactic relations within the complex clausal, leading to a review of constituency boundaries. In (1b), even assuming the syntactic function of direct object of the matrix predicate, the argument Harriet remains the semantic subject of the predicate completive clause. Thus, the raising would be linked to a change in the morphosyntactic relation, not in semantic relations.

In his description, Noonan (2007, p.79) states that raising would be a

[...] method whereby arguments may be removed from their predications resulting in a non-s-like complement type. This method involves the placement of an argument notionally part of the complement proposition (typically the subject) in a slot having a grammatical relation (e.g. subject or direct object) to the CTP [complement taking predicates]. This movement of an argument from a lower to a higher sentence is called raising.

Based on the definition offered by the author, I can extract some relevant aspects to the characterization of raising. Firstly, the raised NP is semantically part of a completive clause 4, that is, it is an argumental constituent of the embedded predicate, not of the matrix predicate. Secondly, raising is a phenomenon that typically (but not only) affects the subject of the embedded clause, which when raised, develops grammatical relations with the matrix predicate, that is, it will be its subject or its object. Thirdly, after the raising, the complement clause takes the reduced form (infinitive), rendering it non-sentence-like.

\footnotetext{
${ }^{3}$ The phenomenon of equi-deletion refers to erase of the NP of coreferential completive clause to some term of the matrix clause, as in Zeke $e_{i}$ wants $\emptyset_{\mathrm{i}}$ to plant the corn, in which the subjects of the matrix predicate wants and the embedded predicate to plant are the same. It can also occur erasing of coreferential matrix clause's term to completive clause's term, if identified as equi-deletion to the back (NOONAN, 2007, p. 75-79).

${ }^{4}$ In this study, I interchangeably used the terms subject, completive/complement and embedded to refer to the sentence/clause in argumental positions of a matrix predicate or one of its constituents.
} 
This definition by Noonan (2007), not least for a functional characterization of raising is the use of terms such as placement, movement and, in the identification of the phenomenon itself, the term raising, around which hovers a theoretical discussion on the use of these terms to refer the raised NP. To put it briefly, placement and movement seem theoretically incompatible terms with clearer properties of the phenomenon because the first of them refers to the position of constituent motivated by syntactic, semantic and pragmatic reasons, as claimed by functionalists (cf. DIK, 1979; 1981; 1989), and the second refers to the transformation operation on the counterpart without raising, as the phenomenon originally was described by the theoretical apparatus of generative grammar (POSTAL, 1974). Thus, the difference between these two theoretical approaches refers to how each one conceives the origin of the raised constituent: as a result of movements of the constituent of a hierarchically lower position to a higher one in the clause, as a generative postulate, or as a result of pragmatic, semantic or morphosyntactic motivations that lead the constituents to take the position that they occupy in the sentence structure, as a functionalist postulate; that is the perspective adopted in the present study. ${ }^{5}$ Concerning this difference, within the Functional Discourse Grammar, Hengeveld and Mackenzie (2008) declare.

Note that, though we use the traditional terms 'raising' here, we do not want to suggest that the phenomenon involves the transformation of one basic configuration into another derived one (HENGEVELD; MACKENZIE, 2008, p. 368).

I consider, then, that a semantically constituent argument of the completive clause and syntactically argument of the matrix clause is in a relation of raising. This term that also remains borrowed from formal linguistics, without this borrowing means, in the models of Functional Discourse Grammar (HENGEVELD; MACKENZIE, 2008), I envisage that the phenomenon is motivated by processing operations, such as rules of movement of constituents of a deep structure of the clause for a surface structure, as suggested by the generative school (cf. QUÍCOLI, 1976; PERLMUTTER, 1976; KATO; MIOTO, 2000; FERREIRA, 2000; MIOTO; KATO, 2002; MARTINS; NUNES, 2005), but by rules of placement of constituents pragmatically motivated (cf. DIK, 1981; 1989) ${ }^{6}$.

Some implications of Noonan's (2007) definition of raising may be addressed herein. The first one is that raising is a discrepancy between Syntax and Semantics: in the case of raised arguments, semantic relations are maintained, but their syntactic relations are altered, leading to the discrepancy (or misalignment) between functions of representational level (semantic) and functions of morphosyntactic level (GÁRCIA VELASCO, 2013). A second implication would always involve pairs of constructions, which excludes of the phenomenon, cases of raising where there is no a raised counterpart of the pair, as seen in BP in the pair of sentences John believes that [Mary is pregnant] and John believes Mary [be pregnant]. ${ }^{7}$ Finally, the last two implications of adopting the formal approach are morphosyntactic adaptations involving raised argument and complement clause: the morphosyntactic adjustments of raised NP involve an agreement relation and morphological case assignment (in languages that require it), for the matrix predicate, and infinitive expression of embedded clause (SERDOBOL'SKAYA, 2008). If this last adjustment is postulated as necessary for the identification of the phenomenon, three possible scenarios unfold: (i) reduction of embedded clause to the infinitive form is optional and, therefore, the phenomenon is also compatible with embedded clause in infinite form, as in BP (children look like they are tired), or (ii), if embedded clause remains in finite form, dealing with a case of raising itself is out of the scope of the present study, but simple topicalization, or (iii), even loss of sentence properties, leading to a codification of verb in infinite form, cannot be a clearer property of the phenomenon. I will take this issue further.

Not only the subject of the embedded predicate is affected by raising. In addition to the subject, the direct object can also be affected. As to the position where the constituent will be raised, it usually corresponds to the position of the subject, but it is possible that the constituent occupies also the position of direct object of the matrix predicate, characterizing the plurality of types of raising shown in (2) and (3), which are examples of English, and (4), examples of Irish.

\footnotetext{
${ }^{5}$ Even if I recognize that the proposal of the Generative Grammar is much broader than the one presented in this paper; I assume that a purely morphosyntactic analysis of Raising does not sufficiently account for the description of the work, from a functionalist perspective.

${ }^{6}$ For a functionalist analysis, in BP, check out the works of Andrade $(2015 ; 2016 ; 2018)$ and Andrade and Gonçalves (2016).

${ }^{7}$ In this case, the fact that, in BP, the Mary NP cannot be interpreted as a case of ASO is due to the impossibility of it being in the form of a pronoun, exposing, thereby, assigning accusative case, as in ${ }^{\star}$ John believes to be pregnant.
} 
(2) English: Subject-to-Subject Raising (SSR) (NOONAN, 2007, p. 81)

a. It seems [that Boris dislikes vodka]

b. Boris seems [to dislike vodka]

(3) English: Object-to-Subject Raising (OSR) (NOONAN, 2007, p. 81)

a. It's tough for Norm [to beat Herb]

b. Herb is tough [for Norm to beat]

(4) Irish: Object-to-Object Raising (OOR) (NOONAN, 2007, p. 82)

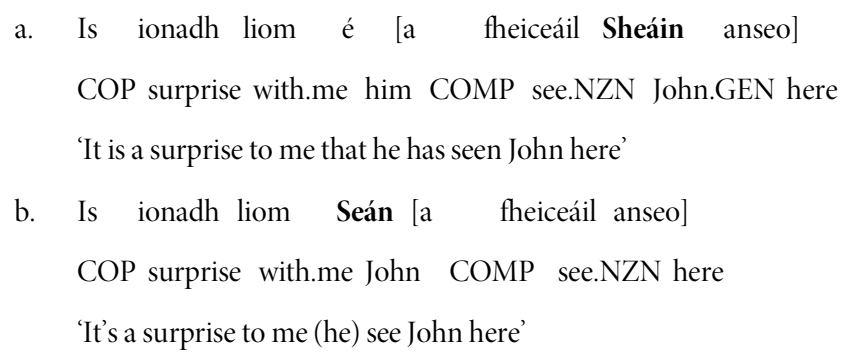

In (2) there is an example of one of the most productive raisings, the SSR: Boris, in (2a), the subject of the complement predicate, is raised to the subject of the matrix predicate in (2b), leading to a reduction of complement clause. In (3a), Herb works as the direct object of the embedded predicate and, in ( $3 b$ ), its morphosyntactic relation is modified along with a reduction of supplement clause, starting to play the role of subject of matrix predicate and characterizing raising of object to subject (from now on, OSR). In (4), the raising is the position of object to object (OOR, henceforth), one of the least translinguistically productive types of raising according to Gárcia Velasco (2013). In this example from the Irish language, the motivations for raising occur gradually: in (4a), equi-deletion occurs because of coreferentiality between the subject of the embedded and the argument of the matrix, so in the matrix, the form of accusative is 'it' occurs as a nominative is 'he', one of the motivations for the raising of Sheáin of nominalization constituent to the predicate object ionadh. According to Noonan (2007), in cases such as these where there is equi-deletion and complement clause comes with a nominalized term, the raising is compulsory in Irish. In the examples offered by the author, it is possible to observe that, intralinguistically, not all types of raising are productive, as is the case for English OOR (NOONAN, 2007, p. 81).

Finally, it is possible to observe that, despite the fact that Noonan's (2007) typological work has a strong appeal in functionalist overview of subordination, particularly regarding raising, he does not highlight any properties of semantic and pragmatic orders involved in the phenomenon. On that account, I resort to the work of other authors in order to maintain my commitment to a functionalist orientation.

According to Givón (2001a), topicality, one of the Grammar subsystems oriented to the speech, is defined as a property of NP and is typically encoded as subject (primary topic), but it may also be encoded as object (secondary topic). Topicality, even reflected in the clausal level, is dependent on the speech. In addition, according to the author, topicality is related to the iconic principle of sequentially, whereby "a slice of the most important information is put forward". In relation to raising, the raised term would be put forward in a grammatical relation to the matrix predicate by pragmatic motivations, that is, a constituent topic is brought to the left, in which case it may lose its relations with the embedded predicate (GIVÓN, 2001a, p. 35).

From the functionalist assumptions of Givón, the human language has two main functions: representation and communication of knowledge/experience. To the representation function, underlie the levels of semantic-propositional, lexical information and 
discursive consistency whilst to the communication function, underlie the communicative encoding by a peripheral sensorimotor code and grammatical code. Therefore, when I consider the syntactic level of clause, there is always the possibility that the same content be encoded in different ways, which helps to explain certain linguistic phenomena, among which raising. Therefore, topicality is related to two aspects of referential coherence: referential accessibility and thematic importance, related, respectively, to how - according to the Speaker - the referent is accessible and how important he is. These are two mechanisms that restrict the grammatical choices used in the encoding of morphosyntactic structure, which encode the pragmatic and discursive dimensions of raising constructions, in order to interpret them as strict cases of topicalization. To Givón (2001b), the occurrence of raising is related to the presence of a verb of mental activity with propositional argument and another nominal argument. Within the propositional argument, an NP is given as a topic, normally, the subject, and, because of its importance, it is raised from the subordinate position to the argument (subject or object) of the matrix.

As confirmed by Görski (2008), in BP, topicalization is pragmatically motivated but not restricted to cases of impersonality and semantic type of verb of mental activity, as proposed by Givón (2001b). However, BP is sensitive to the definiteness of the NP and other features, such as (i) the use of the preposition to (de) before the infinitive and (ii) the possibility of moving a constituent adverbial, locative, which, occurring in nominal form, competes the subject function of the matrix clause, as shown at (5) and (6), respectively.

(5) Doc:: J. a sua mãe me falô(u) que cê sabe fazê(r) um bolo de chocolate muito bom:: eu gostaria que você me explicasse como que é esse bolo de chocolate Inf.: ah ele é assim ele é fácil de fazê(r) né? (AC-048-TRANS-304-306)

(Doc.: J. your mother told me that you know how to make a good chocolate cake:: I'd like you to explain to me how to bake chocolate cake Inf.: well, it is easy to make, right?)

(6) o Império publica uma lei... que dava direito aBRIa a possibilidade... das pessoas que se... instaLAssem em terras... públicas portanto terras ((barulho de carros)) devolutas é difícil que se estabelecessem... criassem as suas RAÍzes nesses locais construíssem suas casas... os seus... é:: tiv/ mantivessem os seus reban::hos... (AC-146TRANS-94-98)

(the Empire publishes a law... that used to give the right oPENed the possibility... of people that... live in lands... public, so vacant ((car noises)) lands is hard that they live... create their roots in those places, build their houses... their... hum:: keep their herds...)

It is possible to observe a case of OSR in (5). In the canonical structure 8, the clause would be coded as it is easy to do it, right, in which the pronoun it refers to the related topic cake. I also observed that there is a pragmatic motivation for the raising: the NP is an important and relevant discursively constituent, that is, it is the part of speech act that has contextual relevance, and which will be redeemed within the communicative interaction. Therefore, there is the constituent raising, corroborating Gorski's (2008) statement; the infinitive is introduced by the preposition.

In (6), I notice a structure of raising of locative term in subject position. One feature that is apparently part of this type of raising is the deletion of the preposition: thus it is difficult to settle on public land.

In Serdobol'skaya's work (2008), there is a definition of raising that incorporates the retake defined by Noonan: an argumental constituent of the embedded begins to function as an argumental constituent of the matrix. According to the author

${ }^{8}$ Following the extensive literature on the ordering of constituents for BP, I consider the following canonical order SVO (Subject-Verb-Object) in a declarative way (cf. BRIDGES, 1987). 
$[\ldots]$ it has been argued that the noun phrases (NPs) [...] are 'raised', because they show morphosyntactic properties of the matrix verb's argument (direct object or subject), while semantically they belong to the embedded clause (SERDOBOL'SKAYA, 2008, p. 269).

However, unlike Noonan's proposition, the author presents other questionable casesof raising, in addition to the cases with the raised object or the raised subject, for example, the case of reflexive and coreferential pronouns. Take the example in (7), provided by the author.

(7) Jack believed himself to be immortal (SERDOBOL'SKAYA, 2008, p. 71)

In (7), the pronoun himself, translated into Portuguese by the particle $s e$, is, at the same time, direct object of believed predicate and subject of immortal predicate. In addition to being coreferential, the pronoun is reflexive, that is, it encodes both referent matrix object and the subject of the embedded clause. Initially, based on the criteria proposed by Noonan (2007), I attest the status of the clause as raising in (7). However, some of the structural differences that can be seen in Serdobol'skaya's and other examples used in the literature lead me to question the status of raising in (7). By observing the coded structure, it is possible to find similarity with the phenomenon of equi-deletion - such as Lexical Functional Grammar (FOKKENS, 2010) - since the finite verb of the matrix takes the subject as a coreferential argument to another of embedded, which leads to deletion of the coreferential argument, thus setting an anaphoric control, unlike what occurs with predicates of raising, in which there is a functional control, in Fokkens' (2010) terms. Another factor that leads me to question the status of raising in the example in (7) is the fact that the matrix predicate provides, semantically, in its argumental structure, two arguments, which provides no cases of raising.

Serdobol'skaya's (2008)greatest contribution is to criticize Noonan's definition. Similarly, to what he has proposed, Serdobol'skaya identifies not only that the subject can be raised, but, differently, he presents the raising of indirect objects and not argumental NP, found in the language Kipsigis, and adverbial clauses present in Altaic languages. Similar structures have been identified by Görski (2008) when addressing the topicalization of adverbial adjuncts. In addition to these languages, Serdobol'skaya shows that, in Quechua, different types of constituents can be raised and, in Irish, temporal clauses, with simultaneity between the time of the stateof-things of matrix clause and of embedded clause are also raised, something also addressed by Görski for BP.

\section{THE MANIFESTATION OF THE PHENOMENON IN BP}

In BP, I identify the types of raising shown from (8a) to (11a), extracted from the corpus that served as empirical research and/or a manual of the description of Portuguese, as explained, in each case, what constitutes raising with no counterpart from (8b) to (11b). ${ }^{9}$

(8)

SSR

a.

a informante parece [pensar em algo mais para dizer] (AC-004; 63)

(the informant seems to [think of something else to say])

b. Parece que a informante pensa em algo mais para dizer (It seems that the informant thinks of something else to say)

c. A informante parece [que pensa em algo mais para dizer] (The informant seems [to think of something else to say])

(9) OSR

a. o serviço é difícil [arranjá(r)] (AC-071; 135) (the job is hard to [get])

\footnotetext{
${ }^{9}$ At the end of each occurrence extracted from the corpus, I respectively identify, the sample type (AC, sample census, or AI, sample interaction), the number of the survey and the line from where the data was extracted.
} 
b. É difícil arranjá(r) serviço

(It's hard to get a job)

c. ?? O serviço é difícil [que se arranje].

(?? The job is hard [to get]).

(10)

\section{SOR}

a. O professor mandou os alunos [entregarem os trabalhos datilografados] (SOUSA E SILVA; KOCH, 2009, p. 110)

(The teacher ordered the students [give typed works])

b. O professor mandou [que os alunos entregassem os trabalhos datilografados] (The teacher ordered [that the students give typed works])

c. O professor mandou-os [entregar os trabalhos datilografados] (the teacher ordered them [to give typed works])

$(11)$

OSR

a. As provas do processo confirmaram (o réu) [ser (o réu) um estelionatário] (SOUSA E SILVA; KOCH, 2009, p. 110)

(The evidence of the process confirmed (the defendant) [be (the defendant) a swindler)

b. As provas do processo confirmaram [que o réu é um estelionatário]

(The evidence of the process confirmed [that the defendant is a swindler])

c. ?? As provas do processo confirmaram-no [ser um estelionatário].

(?? The evidence of the process confirmed him [be a swindler).

In (8a), there is a prototypical structure with raising promoted by a matrix predicate of epistemic modality, the verb seem: the subject of the embedded clause occurs in the slot to the left of the matrix verb, taking on, in this new domain, the syntactic function of subject and initiating agreement. This is the prototypical structure due to maintenance of all raising criteria offered by Noonan (2007), including reduction of complement clause. This example is a case of RSS, that is, raised NP, before, syntactic subject of the completive clause, as seen in (8b), occurs as the syntactic subject of the matrix predicate (8a). Note that despite having lost its morphosyntactic relation with the completive clause, he keeps his semantic relationship within it. The reconstruction (8c) shows that the reduction of the embedded clause, even in a structure similar to raising, is not a required property, at least for this type of semantic of matrix predicate.

In (9a) and its correspondingly not raised (9b), there is an example of OSR, favored type by evaluative predicates like (is) easy/difficult. The job NP, in (9b), is the direct object argument of the embedded predicate get; with morphosyntactic adjustment, resulting in the construction with NP raised (9a), it is attributed to it the syntactic function, now, the subject of the matrix predicate. Again, despite having lost syntactic relations with the embedded predicate, it still maintains its semantic relation with him. For this kind of raising, the reducing of the completive clause is also categorically noted, with the difference that it is rare (if not strange) that a counterpart-without-raising occurs in finite form, as shown in $(9 \mathrm{c})$. 
The occurrences in (10a) and (11a) ${ }^{10}$ are raised structures and correspond to their non-raised counterparts in (10b) and (11b). Following the model described by Noonan, in these examples, according to Lehmann (1988), the embedded clause loses properties of full clause, such as finite. In (11a), there is still postposition of the semantic subject defendant to the verb be of the embedded clause, something that, according to Souza e Silva and Koch (2009), would mark an alternative stylistic choice to The evidence of the process confirmed [the defendant is a swindler), confirming, thereby, that this is the case of SOR, how it shows well the pronominalization of the accusative case, totally acceptable in (10c), but debatable in (11c).

As far as I have examined, cases of OOR in BP are not certificated, or they are less productive, like the SOR. As should be clear from the above analysis, not all of the criteria offered by Noonan (2007) to identify the phenomenon of raising apply consistently to BP:

maintenance of argumental relations (semantic) between the raised NP and the embedded predicate: applicable to all three types found in BP; criterion for the three types of raising found in BP (although, in all instances observed in the corpus, the raised argument of NP of the third singular person, restricting, thereby, the unequivocal verification of this property);

reduction of the embedded clause: optional criterion for SSR, but mandatory for cases of OSR and SOR, optionality is due to the semantic of predicate matrix; with predicates matrices of epistemic modality, which strongly favor the RSS, the reduction of the embedded clause is optional or it is a kind of only approximated raising, which brings me to stay with the first alternative; with evaluative predicate matrices or confirmatory, more correlated with ROS and RSO, clause reduction seems to be a mandatory property.

\section{RESULTS FOR THE SSR IN BP}

Based on studies that have analyzed the raising of constituents in BP (cf. MITTMANN, 2006; HENRIQUES, 2008; MARTINS; NUNES, 2005) or similar phenomena such as topicalization (cf. GÖRSKI, 2008), a set of analysis criteria was proposed to investigate cases of SSR and it allowed assessing relevant properties for this specific type. Note the occurrences in (12) and (13), the two main types of semantic predicate: modality predicate seems, the most productive for the SSR (12a-f), and evaluative predicate of type easy/difficult, correlated with both SSR (13a) and OSR (13b); in this section, only the first one is of interest.

(12) a. essa pelo menos parece que é artista (AC-147; 337)

(this at least seems that is an artist)

b. $\quad$ ele conta que a escritu::ra parece que tinha ficado em mãos de terce(i)ros... (AC-146; $150 / 151)$

(he tells that the contract seems that had been in other hands...)

c. a gente que percebe porque o pai parece que num tem noção de percebêe(r) que a criança num tá bem... (AC-086; 551/552)

(we realize why the father seems to have no idea that the child is not well...)

d. os pais:: eles parece que têm... uma barre(i)ra com a gente que é incrível... sabe?... (AC086-;523/524)

${ }^{10}$ I did not find in corpus any occurrence of SOR, although this type of raising may also be manifested in BP. Therefore, I turn to examples of Sousa e Silva and Koch (2009) to assert the existence of such raising. 
(his parents... they seem to have... a barrier with us which is unbelievable... You know?)

e. o cara num parece tê(r) setenta anos de idade (AI-005;178)

(the guy does not seem to be seventy years old)

f. a gente percebe que as histórias dele realmente aconteceu [Doc.: uhum ((concordando))] mas tem uma.... que/ eu num tava perto não... ele ele que conta ele e minha mãe eles conta... pa/ parecem sề(r) verdade também... (AC-086; 147)

(we realize that his stories really happened [Doc.: hum ((agreement))] but there is one... that/ I was not nearby... he he tells he and his mother they tell... it/ also seems to be truth...)

(13) a. atrapalha muito... o namoro é difícil pra andá(r) pra frente né? eu a/ eu penso assim (AC$046 ; 410 / 414)$

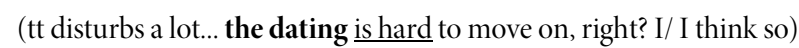

b. e eu dobro toalha tam(b)ém (inint.) toalha é compliCAdo pa caramba pa dobrá(r)... mui/ tem muito detalhe... tem que dobrá(r) ela no me::io depois no meio de no::vo... (AC-016; 353/360)

(and I also fold the towel... the towel is so hard to fold... there is a lot of detail... it has to be folded in the middle, after that in the middle again...)

Based on the data collected in the corpus, I consider that, for SSR in PB:

(i) there is no pronoun copy in the embedded clause;

(ii) the clausal reduction is optional, given the occurrence with finite embedded predicate (12a-d) and nonfinite predicate ((12e-f), (13a));

(iii) morphosyntactic adjustments occur of raised NP, involving a relation of agreement ((12a, b, c, e, f), (13a)) or not (12d) with the predicate matrix and/or to the embedded predicate (12a, b, c);

(iv) the semantic type of the matrix predicate is an extremely relevant factor to specific types of raising; the specific case of SSR is more favored for epistemic predicates (type of to seem) and less by evaluative (the type is easy); these more conducive to chaos of OSR (13b);

(v) as to an informational statute of raised constituent, in most instances, raised constituents represent given topic $((12 a-f),(13 a, b))$, and defined reference $((12 a-f),(13 a))$, which converges with the topicality factor.

\section{CONCLUSION}

Based on the literature about raising and topicalization of constituents, it is possible to uncover a set of criteria which allows for identifying constructions of raising, a phenomenon that, consensually, involves the recognition of an argument that is semantically the argument of a completive clause, but that occurs within the limits of a clause to the highest level, in the field which contracts new morphosyntactic relations. 
Following this definition, in BP, there can occur the raising of constituents of a subject position of completive clause to subject of matrix clause, subject of completive clause to object of matrix clause and object of completive clause to subject of the matrix clause. For all these cases recognizable in languages in general, the following parameters seem sufficient for the identification of the phenomenon: (i) the presence of two clauses; (ii) morphosyntactic adjustment in the new field of raised constituent; (iii) loss of clausal properties of the embedded clause (explicitness of subject, illocutionary force, finiteness, agreement etc.).

In BP, the SSR is favored by epistemic and evaluative matrices predicates, semantic types that attest to the following criteria: reduction of embedded (with more evaluative and less epistemic) and agreement of the raised item with the matrix predicate (also with two types), in addition to these properties, another exclusive of evaluative is the embedded that may or may not come introduced by preposition. As for semantic-discursive properties, the SSR is more correlated with NP with given and inferred informational status, which reveals that the topicality of the constituents is a relevant factor for raising, since topic constituents tend to occur on the left. Also related to the informational status, raising focuses more often on defined generic or specific reference NP but rejects the undefined reference NP. Animacy does not seem to be a decisive factor for raising to happen, allowing the occurrence of the phenomenon of NP with regard to both inanimate and human.

Given these preliminary results, I then agree to the fact that for BP, out the types of Raising verified in natural languages, the SSR is the most productive, albeit with few occurrences in spoken modality (only 30). These results lead me to have to expand my research corpus to include written modality.

It was also possible to certify the sufficiency of the morphosyntactic and semantic-pragmatic parameters for the identification of the phenomenon, but not for its current definition, as presented in the literature on the subject, which, in most cases, favors more morphosyntactic criteria than the semantic-pragmatic nature, fact that encourages me to proceed with the investigation in search of a more precise definition.

\section{REFERENCES}

ANDRADE, G. S. Funcionalismo aplicado à sintaxe: alçamento a sujeito no português. Latvia: Novas Edições Acadêmicas, 2018.

ANDRADE, G. S. O predicado parecer na história do português: o caso particular das construções com Alçamento de constituintes. DOMÍNIOS DE LINGU@GEM, v. 10,p. 330-348, 2016.

ANDRADE, G. S. Propriedades tipológicas de Alçamento de SN argumental e suas implicações para o reconhecimento do fenômeno no Português Brasileiro. Estudos Linguísticos, v. 44, p. 376-389, 2015.

ANDRADE, G. S.; GONÇALVES, S. C. L . Por uma abordagem funcional de constituintes argumentais. In: MARTINS, M. A.; JÚNIOR, L. A. de S.; MOURA, K. K. de; MORAIS, A. da S. (org.). Estudos Linguísticos: textos selecionados/ABRALIN 2013. João Pessoa: Ideia, 2016. p. 224-242. 
DIK, S. C. The interaction of subject and topic in Portuguese. In: BOLKSTEIN, A. M. et al. (org.). Predication and expression in functional grammar. London: Academic Press, 1981. p. 165-183.

FERREIRA, M. B. Argumentos nulos em português brasileiro. 2000. Dissertação (Mestrado em Linguística) - Instituto de Estudos da Linguagem, Universidade Estadual de Campinas, Campinas, 2000.

FOKKENS, A. Raising and control in LFG. 2010. (mimeo).

GÁRCIA VELASCO, D. Raising in functional discourse grammar. In: MACKENZIE, J. L.; OLBERTZ, H. (org.). Casebook in functional discourse grammar. Amsterdan/ Philadelphia: John Benjamins, 2013. p. 249-276.

GIVÓN, T. Syntax: an introduction. v.1. Philadelphia: John Benjamins, 2001a.

GIVÓN, T. Syntax: an introduction. v.2. Philadelphia: John Benjamins, $2001 \mathrm{~b}$.

GONÇALVES, S. C. L. Banco de dados Iboruna: amostras de fala do interior paulista. 2007. Disponível em: http://www.iboruna.ibilce.unesp.br

GONÇALVES, S. C. L.; SOUSA, G. C.; CASSEB-GALVÃO, V. C. As construções subordinadas substantivas. In: ILARI, R., NEVES, M. H. M. (org.). Gramática do português falado no Brasil, coordenação geral: Ataliba de Castilho. Campinas: Editora da Unicamp, 2008. p. 1021-1084.

GÖRSKI, E. Reflexos da topicalização sobre o estatuto gramatical da oração. In: VOTRE, S.; RONCARATI, C. (org.) Anthony Julius Naro e a linguística no Brasil: uma homenagem acadêmica. Rio de Janeiro: 7Letras, 2008. p.169-185.

HENGEVELD, K.; MACKENZIE, J. L. Functional discourse grammar: A typologically-based theory of language structure. Oxford: Oxford University Press, 2008.

HENRIQUES, F. P. Construções com verbos de alçamento: um estudo diacrônico. 2008. Dissertação (Mestrado em Linguística). Universidade Federal do Rio de Janeiro, Rio de Janeiro, 2008.

HOPPER, J.; TRAUGOTT, E. Grammaticalization. 2. ed. Cambridge: Cambridge University Press, 2003.

KATO, M.A.; MIOTO, C. A inexistência de sujeitos oracionais. Rio de Janeiro: Laços, 2000. p. 61-90. 
LEHMANN, C. Towards a typology of clause linkage. In: HAIMAN, J., THOMPSON, S. (org.). Clause combining in grammar and discourse. Amsterdam/Philadelphia: John Benjamins, 1988. p. 275-330.

MARTINS, A. M.; NUNES, J. Raising Issues in Brazilian and European Portuguese. Journal of Portuguese Linguistics, v. 4, n. 2, p. 53 $77,2005$.

MIOTO, C.; KATO, M. A. Aspectos sintáticos da subordinação sentencial. In: ABAURRE, M. B.; RODRIGUES, A. C. S. (org.). Gramática do português falado: novos estudos descritivos. v. iii. Campinas: Editora da Unicamp, 2002. p. 379-411.

MITTMANN, M. M. Construções de alçamento a sujeito: variação e gramaticalização. 2006. Dissertação (Mestrado em Linguística)

- Programa de Pós-Graduação em Linguística, Universidade Federal de Santa Catarina, Florianópolis, 2006.

\section{(c) (1) $\circledast \ominus$}

